This is a self-archived version of an original article. This version may differ from the original in pagination and typographic details.

Author(s): Salminen, Hanna; Wang, Qian; Aaltio, liris

Title: Aging as a topic in a business magazine : an opportunity or threat for management?

Year: 2019

Version: Accepted version (Final draft)

Copyright: @ Emerald Publishing Limited, 2018

Rights: In Copyright

Rights url: http://rightsstatements.org/page//nC/1.0/?language=en

Please cite the original version:

Salminen, H., Wang, Q., \& Aaltio, I. (2019). Aging as a topic in a business magazine : an opportunity or threat for management?. Baltic Journal of Management, 14(2), 198-211.

https://doi.org/10.1108/BJM-05-2018-0180 


\section{Emerald $\begin{aligned} & \text { Baltíc Journal } \\ & \text { of Management }\end{aligned}$}

\section{Aging as a topic in a business magazine: an opportunity or threat for management?}

\begin{tabular}{|r|l|}
\hline Journal: & Baltic Journal of Management \\
\hline Manuscript ID & BJM-05-2018-0180.R2 \\
\hline Manuscript Type: & Original Article \\
\hline Keywords: & $\begin{array}{l}\text { Aging, Individual/organizational/societal level, Corporate social } \\
\text { responsibility (CSR), Finland, Ageism, Media }\end{array}$ \\
\hline \multicolumn{2}{|l}{} \\
\hline
\end{tabular}

\section{SCHOLARONE \\ Manuscripts}




\title{
Aging as a topic in a business magazine: an opportunity or threat for management?
}

\begin{abstract}
Purpose - Recently, research on aging in the work life context from the perspective of how to manage, support and retain an aging workforce has increased among management scholars, and therefore is contributing to the current societal need to extend work careers. This study analyzed articles discussing aging in the work life context in the Finnish business magazine Talouselämä (Economic Life) during the years 2002-2017.

Design/methodology/approach - A total of 81 articles were included in the analysis. They were classified into seven themes as a result of a content analysis. Three levels of discussions on aging were identified: societal, organizational and individual. These levels were further analyzed in order to revel what kind of issues have been emphasized or overlooked. The results were discussed in the context of Finnish work life.

Findings - The findings showed that aging has been presented in a passive and deterministic (or at least neutral) tone. Most of the articles focused on the consequences and actions related to an aging workforce at the societal level. At the individual level, aging was mainly discussed in terms of changes related to work ability and functioning, with aging individuals as the actors responsible for managing and controlling the effects of their own aging process. The organizational-level discussion on aging was limited and narrow, mostly lacking any discussion of the role of organizations as responsible actors or from the perspective of Corporate Social Responsibility (CSR).

Practical implications - Organizations could take a more active and broader role in terms of supporting the longer working careers of older employees. Professional magazines could deal more with "age-aware" research as it relates to organizations, especially the potential and opportunities of the aging workforce. Aging research could promote media level publishing and applications of knowledge.
\end{abstract}

Originality/value - Few critically oriented management studies have investigated how aging is presented and discussed in business magazines.

Keywords Aging, Individual/organizational/societal level, Corporate social responsibility (CSR), Magazine, Finland

Paper type Research paper 


\section{Introduction: critical notions of age and aging}

From a broad global perspective, the number of people over 65 years of age is growing rapidly (Mahon and Millar-Schijf, 2014). As a global phenomenon, aging has been referred to as "disruptive demographics" (Aaltio et al., 2016; Coughlin, 2010). The main reasons for the aging population are lower rates of fertility and mortality, and greater longevity (Chand and Tung, 2014, p. 410). For instance, Finland, among other Western countries, faces substantial growth in the aging population. According to statistics, this trend is intensifying: The number of those aged over 65 will increase by approximately 26\% every 10 years from 2020 to 2060 (Statistics Finland, 2015). People living longer has several societal outcomes (Mahon and Millar-Schijf, 2014), such as the increasing need for healthcare services, as well as worsened dependency ratios. In Western societies, policy-makers are trying to respond to these challenges by promoting the extension of work life by postponing the retirement age and reducing early exits (Buyens et al., 2009; Henkens et al., 2008; Lain and Loretto, 2016; Parry and Tyson, 2009; Walker, 2005).

However, the effects of aging will differ across countries and regions, and therefore, various priorities and practices prevail (Chand and Tung, 2014). For instance, in Latin America, questions of health are emphasized in discussions at the societal level (Palloni and McEniry, 2007). Whereas, in certain developing countries, it has been estimated that people will age before they become wealthy, which leaves less time for governments to cope with the challenges related to aging (Beard et al., 2012, see Chand and Tung, 2014, p. 409). When it comes to actions at the organizational level, age management as a tool has been more actively discussed and employed in European countries compared to the United States (Mahon and Millar-Schijf, 2014).

Aging as a research topic comprises discussions at societal, organizational and individual levels. Furthermore, these levels are interrelated (Ilmarinen, 2006). For example, changes in retirement policies at the societal level influence how individuals prepare for their exit from work life and plan their retirement (Laliberte Rudman, 2015). Furthermore, the aging workforce present challenges for organizational policies and practices, such as human resource management (HRM) (Chand and Tung, 2014). Although aging is a multidisciplinary research topic, links between management studies and other fields, such as sociology and economics, have only just started to emerge (Chand and Tung, 2014). In management studies, aging in the organizational context has been studied from different perspectives (Aaltio et al., 2014), such as stereotypes related to aging employees (Brough et al., 2011; Hedge et al., 2006), workplace efficiency, career development and retirement policies (Kanfer and Ackerman, 2004), and the HRM practices needed to support the workability and retention of aging employees (Ilmarinen, 2006). Most of these management studies have focused on different types of practices for managing the older workforce, including leadership and HRM practices, which are often called age management or age-aware HRM practices (Walker, 2005).

However, aging in the organizational context has rarely been approached from a critical perspective (Fineman, 2014; Thomas et al., 2014). For example, few studies have investigated how aging is presented and discussed in the mass media (Rozanova, 2010; Laliberte Rudman and Molke, 2009). Rozanova (2010) analyzed articles published in the Canadian daily newspaper The Globe \& Mail and examined how successful aging was featured in different 
contexts. Laliberte-Rudman and Molke (2009) analyzed how "productive aging" was portrayed in Canadian newspaper articles. Both studies drew on critical gerontology. This study draws mainly on the management perspective, and more specifically, HRM literature, and investigates how aging in the work life context has been discussed in a Finnish business magazine. In line with Rozanova's (2010) and Laliberte-Rudman and Molke's (2009) studies, this paper assumes that thoughts, opinions and reflections in society about aging are brought to life through media outlets, such as magazines. This study is qualitative, and the empirical data based on articles published during the last 16 years in the magazine Talouselämä (Economic Life) - one of the main business magazines in Finland. By using content analysis, the aim is to examine not only how the discourses at societal, organizational and individual levels are interconnected, but also how they differ and contradict each other. Furthermore, we explore how the role of organizations and management practices are discussed in relation to aging in the work life context. The research questions are as follows:

- How is aging in the work life context discussed at societal, organizational and individual levels in a Finnish business magazine between 2002 and 2017 ?

- What is the specific role of organizations and management in dealing with the aging workforce, according to these discourses?

This paper is organized as follows. The theoretical background of the study is presented after the introduction. This is followed by the methodology section, which describes how the empirical data were collected and analyzed. Then the empirical findings are presented. In the discussion and conclusions, the main findings are discussed in relation to the theoretical framework and previous studies. Practical implications, limitations and suggestions for future research are also provided at the end of the paper.

\section{Theoretical background: individual, organizational and societal approaches to aging}

At the individual level, aging concerns physical, mental and social changes, which vary among individuals (Sterns and Miklos, 1995; Ilmarinen, 2006). In the work-life context, physical changes are often seen as the most visible part of aging. Therefore, emphasis has been placed on, for example, work ability which describes the balance between an individual's resources and his or her work demands and how they change due to aging (Ilmarinen, 2001, 2006). Although physical abilities tend to decline during aging, psychological and cognitive abilities, such as expertise and wisdom, usually accumulate resulting in "crystallized intellectual intelligence" (Cattell, 1943, 1981; see Kanfer and Ackerman, 2004, p. 443). In other words, the relationship between aging and performance is complex and not necessarily negatively related (Sterns and Miklos, 1995). Despite this, negative stereotypes about the ability of aging employees to perform are common, influencing managerial decisions and practices, and therefore having harmful consequences for aging employees (Brough et al., 2011; Hedge et al., 2006; Hertel et al., 2013). For example, Thomas et al. (2014, p. 1573) used the term the "grey ceiling" to illustrate a situation where negative assumptions and prejudices influence how aging employees are treated in organizations.

At the societal level, negative stereotypes of aging employees can cause unnecessary early exits from the workforce. However, the way aging has been seen and valued may vary 
based on cultural differences at the societal level. For instance, some Eastern values may support aging at the cultural and historical levels (Leung, 2000) but there is usually an ambivalence concerning the value of older individuals in work life (Chand and Tung, 2014). For example, the association between aging and innovation seems to be problematic (Aaltio et al., 2016).

During the past decade, many countries, such as European countries, have undertaken large reforms to reduce the costs of early retirement (Carone et al., 2016; Sonnet et al., 2014). For example, in Finland, extensive pension reforms took place in 2005 and 2017 (Carone et al., 2016; Tenhunen, 2017). Laliberte-Rudman (2015) in her critically oriented study pointed out that the current retirement policies related to positive aging discourses which prevail in society influence individuals. In other words, the current neoliberal discourse has emphasized the responsibility of individuals to maintain their youthful healthy and productive appearance, as well as the risks of early retirement (Laliberte Rudman, 2015, p. 11).

In the field of management and organization studies, only a few articles have critically examined aging in the organizational context (see e.g. Thomas et al., 2014). Most of the organization-level studies focusing on aging have been descriptive and normative, and lacking in critical aspects, such as gender sensitivity (Aaltio et al., 2014). For example, the age management perspective has mainly paid attention to the balance between an individual's resources and his or her work demands. These studies explored suitable HRM practices to support the retention of aging employees (Ilmarinen, 2001, 2006; Walker, 2005; Foster and Walker, 2013). However, some researchers have stressed that age is only one category of diversity along with gender, ethnicity and disability (Thomas et al., 2014, p. 1571), and those diverse categories are, in many ways, interconnected (Calasanti and Slevin, 2006). For example, female employees typically receive lower pensions due to breaks in their career path or selecting part-time jobs to match their care responsibilities in the early stages of their career (Foster and Walker, 2013). Older women are seen as more vulnerable to an age-based devaluation in the organizational context (Thomas et al., 2014, p. 1573). Nonetheless, Foster and Walker (2013, p. 6) observed that "most age management policies are gender-blind." Therefore, more attention should be paid to equality in management practices to prevent the accumulation of a gender disparity due to aging (Foster and Walker, 2013). In addition, it has been argued that organizations should be creative in finding ways to respond to the aging workforce (Mahon and Millar-Schijf, 2014, p. 564).

Recently, some management scholars have argued that the management of aging employees could also be approached from the corporate social responsibility (CSR) perspective (Wisse et al., 2018; Ehnert and Harry, 2012). One of the most important goals in CSR is to achieve "social good" by juxtaposing business and environmental sustainability (which has been embedded in the "triple-bottom line"; Wang and Aaltio, 2017). Interestingly, social issues, such as the retention of older employees, have been investigated much less in the field of sustainable HRM compared to environmental issues (Pfeffer, 2010). For example, Wisse et al. (2018, p. 875) found that the relationship between CSR and job satisfaction was stronger among older employees, whose time perspective is more limited, compared to younger employees. They argued that CSR can be considered an important vehicle for organizations to retain and satisfy their older employees. The title of the article is "catering to the needs of an aging workforce" (Wisse et al., 2018, p. 875), an idea which resembles age management and age-aware management. 
According to Strandberg's (2009) report, HR managers are capable of integrating CSR objectives and commitments into business objectives. This idea was deepened by Voegtlin and Greenwood (2016, p. 188), who argued that CSR and HRM are mutually dependent; the two concepts share certain key themes, such as stakeholders (Voegtlin and Greenwood, 2016, p. 188). Based on a systematic review, Voegtlin and Greenwood (2016) divided CSR-HRM research into three categories: instrumental, social integrative and political CSR-HRM. The instrumental CSR-HRM perspective has roots in the neo-classical economics approach, which highlights the passive role of organizations in society and maximizing profit. In contrast, the social integrative perspective sees employees as "human resources and valuable stakeholders" (Voegtlin and Greenwood, 2016, p. 189). According to this perspective, employees need to be involved in CSR-HRM practices to promote the well-being and motivation of individuals, as well as stakeholder value (Voegtlin and Greenwood, 2016, p. 189). Whereas the political CSR-HRM perspective observes the plural interest of different stakeholders and the potential conflicts among them (Voegtlin and Greenwood, 2016, p. 193).

Taken together, challenges and possibilities related to aging in the work-life context cover societal, organizational and individual levels, which are interconnected (Antoniou et al., 2016). The aim of this study is to examine how aging is discussed in a Finnish business magazine in reference to societal, organizational and individual levels. Furthermore, the aim is to investigate the role of organizations and management in dealing with the aging workforce according to these discourses.

\section{Study design, data and analysis}

In this study we ask, how aging is approached in the Finnish business magazine Talouselämä between 2002 and 2017. Talouselämä is published weekly, totaling around 52 issues per year. The magazine focuses primarily on Finnish business life and finance. The articles are in general related to, for example, work life and financial news, as well as their influence on the Finnish economy and society. This magazine is considered one of the most well-known and dominant business magazines in Finland. The primary readership of Talouselämä includes managers and professionals in the Finnish business world. Therefore, the articles it publishes have a wide professional audience of business decision-makers, and it also reflects what kinds of reading material the magazine imagines to be of interest to its readers. Overall, language and textual productions are nowadays common data in studies (Alvesson \& Kärreman, 2000). Media texts are part of the production and re-production of organizational and managerial phenomena (Vaara \& Tienari, 2002).

We selected articles that deal with aging in the work-life context as the basis for our analysis. Articles were sourced from the online archive of Talouselämä magazine. A total of four search rounds were made between 2015 and 2018 in order to ensure the coverage of the relevant articles for the analysis. The term "aging" (ikääntyminen in Finnish) was set as the keyword for the search and 93 articles were found. "Senior" (seniori in Finnish) was also used as a keyword and as a result, found 73 articles. The keyword "age management" (ikäjohtaminen in Finnish) was also used and 10 articles were found. Four duplicate articles, articles in which "aging" was not the primary focus, and articles focused on aging but without any relevance to work life were excluded. As a result, 66 articles were selected based on the keyword "aging" (ikääntyminen), 6 articles were targeted based on the keyword "senior" 
(seniori), and 9 articles were gathered based on the keyword "age management" (ikäjohtaminen). One article was found using two keywords "aging and age management" (ikääntyminen and ikäjohtaminen). Therefore, the sample for analysis comprised 81 articles that deal with aging. ${ }^{1}$ The content in these articles related to aging in the work-life context and fulfilled the screening criterion. The textual data was the focus, and visual data (pictures, figures, statistics and photographs) was excluded from the analysis. After this initial process, the title and the content of each article were carefully and thoroughly read. The content and the length of the articles varied considerably. Most of the articles were short, such as commentary articles or book reviews, while some were longer articles based on interview data, for example. The total number of articles found and the number of articles selected on the basis of their year of publication is presented in Figure I.

\section{Please insert Figure I about here}

The total number of articles has increased during the economic recession and after 2010. This indicates that the visibility of aging issues has grown over the years. However, there is only modest growth in the articles focusing on aging in the work-life context (selected articles).

The analysis was made using qualitative content analysis. A similar type of analysis has also been used in previous studies concerning aging in media outlets (see for example, Rozanova, 2010). At the beginning of the analysis, the articles were read in order to gain a common understanding of the data. One member of the research team used ATLAS.ti software for the preliminary content analysis. The researchers discussed the classifications and decisions in order to verify that the themes were suitable for the data and that there were genuine differences between the themes (Gioia et al., 2012). Each article was categorized based on its main focus. As usual, in magazine articles there is one especially important issue that is emphasized, even if it relates to multiple themes. In the content analysis, a coding unit can vary from a keyword or a phrase to larger units such as a theme (Eriksson and Kovalainen, 2014). In this study, the coding unit was a theme. In other words, the articles were categorized into different themes based on the content. The categorization process can be described as abductive, since the theoretical pre-understanding regarding the research topic served as the point of departure, but themes that emerged from the data were also the focus (see, for example, Rozanova, 2010). The themes were discussed at the team of researchers in order to verify that the themes suited the data, and that there were genuine differences between the themes (Gioia et al., 2012). As a result of the content analysis, seven themes were identified (Table I).

Please, insert Table I about here.

The approach of this study is critically oriented because the aim of the analysis is to identify how the discourses differ or contradict with each other, and to study what kinds of issues have been emphasized or overlooked. Phillips and Hardy (2002, p. 20) distinguished between critically oriented and constructivist approaches to analyzing discourses. They also

\footnotetext{
${ }^{1}$ The list of articles is available from the authors if needed.
} 
distinguished between context- and text-dependent approaches (see Hardy, 2004, pp. 416417). The results of this study are discussed in the Finnish work-life context, and therefore the focus is more context- than text-dependent. To explicate the findings, quotations from the articles are provided.

\section{Findings}

The first theme (Aging and its influences on society) highlighted that aging is a challenge, a threat or a problem for the Finnish economy and society. This viewpoint was often justified by relying on statistics, prognoses or statements presented by experts. The following quotation exemplifies the way aging was discussed in these articles. "According to prognoses, the biggest possible problem will be the aging population: when Baby Boomers retire, there will be all kinds of problems for the working population; not to mention the dependency ratio, which will increase alarmingly" ("Hocuspocus! The retirement bomb has disappeared," Talouselämä, 29.3.2007).

In these articles, aging was described as an inevitable megatrend, and in this way, it was related to climate change, for example, as the following illustrates: "The biggest long-term threat is related to climate change and controlling greenhouse gas emissions. The other huge challenge is the aging population and adapting to it" ("Spain is saved from Spanish disease," Talouselämä, 19.1.2011).

Furthermore, aging was discussed in a deterministic manner and was described as an issue that will happen and that there is little we can do about it at the societal level. In the literature, this has been called "apocalyptic demography" (Gee and Gutman, 2000; see Rozanova, 2010, p. 218). For example, an article titled "More breadwinners, fewer dependents" in Talouselämä (25.11.2010) stated, "Geography is naturally bound to Finland's fate. We are a remote and cold country next to Russia. It has been evident to Finnish people for a long time. What is less obvious is that the age structure of the population is also Finland's fate".

The second theme (Aging as a business opportunity) emphasized the positive consequences of the aging population for Finnish business life. In these articles, aging was seen as one of the megatrends that will have positive consequences for certain sectors, such as pharmaceuticals. In other words, aging individuals were considered potential consumers, and therefore, some companies were seen to benefit from the aging population. The following is from an article that discussed internationalization in Finnish start-up firms and how knowledge and understanding of recent megatrends (such as aging) will benefit these firms: "Finnish people have a good grip on many trends. For example: health, urbanization, recycling and aging". ("The group of very fast-growing Finnish firms plan to go global by taking a shortcut", Talouselämä, 27.12.2016). In the research literature (Chand and Tung, 2014), the changing needs and consumption patterns of the older population have also been acknowledged. For instance, the need for healthcare products and services is expected to grow. In addition, it has been postulated that older consumers will likely increase the demand for redesigned vehicles, such as cars, as well as assistance with living, for example (Chand and Tung, 2014, 2014-2015). 
The third theme (The consequences of aging on work life) is related to the consequences of shifting demographics for labor markets. Articles dealing with this theme focused on the need to prolong work life in response to the aging workforce, aiming to cope with unexpected changes and lower productivity in the labor market. The consequences of aging for the workforce is illustrated in the following: "One reason behind the morbidity and retirement of employees is aging, and the impediments caused by aging". ("Occupational well-being threatens to collapse", Talouselämä, 3.12.2008).

The fourth theme (The consequences of aging on individuals) concentrated on the consequences of aging at the individual level, such as declining work ability and functioning. Most of the articles were descriptive. Some articles presented the "voice" of an aging individual, whereas others relied on academic experts, for example. For instance, one article described the results of an international survey concerning how different aged individuals perceive aging: "The main concern of aging is related to weakening functional and physical mobility as well as financial insecurity among respondents". ("Now it has been studied: the excessive idolization of youth is in the past", Talouselämä, 30.8.2012). Although aging was discussed as an inevitable process, aging was argued to vary according to a person's own life path being heavily influenced by individualized courses of action based on decisions, habits and circumstances. In other words, the responsibility of the individual for aging successfully was emphasized (Rozanova, 2010). Therefore, aging individuals were seen as the key actors and those accountable who need to manage their aging body (Laliberte-Rudman, 2015). This point can be seen in the following: "Aging means the accumulation of years and no one can stop this process; but growing older means biological change, and we can influence the underlying causes of these"). ("Sorry young, the happiest are those over 80 years old", Talouselämä, 6.5.2011).

The fifth theme (Pension-related issues) concentrated on the challenges of the current pension system in Finland and underscored the need to postpone retirement in order to ease the dependency ratio and inhibit the growing expenses related to pensions. In this societylevel discussion, aging individuals were portrayed as a homogenous group without any significant individual differences. For example, an article titled "Don't worry, you just pay more" in Talouselämä (27.5.2009) stated:

The biggest problem in the pension system is the aging population, and especially longevity. When there are fewer people working, GDP growth will slow down. Because of the slower growth, there will be a higher rate of unemployment and consequently there will be smaller pensions. This situation is unpleasant, but the system will try to find a solution to adapt to the situation and to maintain its sustainability.

The sixth theme (Society-level policies needed to respond to the aging population) linked to the previous theme because it depicts decisions and polices, which should be launched in order to tackle challenges related to the aging workforce at the societal level. Articles in this theme had a normative tone. Diverse policy suggestions and implications were illustrated. Although most of the articles primarily showed how difficult the decisions required for the aging population are, some optimistic viewpoints were also presented, for instance:

When it comes to societal decision-making processes, an active policy on aging needs to be addressed more strongly. Due to the age structure of its population, Finland has a unique opportunity to act as a forerunner. We should build a society that offers the 
means for everyone to participate. ("You don't get old, you get through your life",

Talouselämä, 3.6.2011)

The seventh theme (Organization-level age management practices and policies) concerned mainly organizational practices and policies or age management practices targeted at aging employees. In Finland, the Finnish Institute of Occupational Health and their emeritus professor Juhani Ilmarinen have promoted the importance of age management over the years (see e.g. Ilmarinen, 2006). Age management stresses the balance between individual resources and job demands, according to which organizations should find flexible practices in order to retain older employees (Ilmarinen, 2006). The following exemplifies this perspective: "This situation will lead to an endless spiral because work demands increase all the time. One should remember the simple premise that the person does not exist for work, instead work exists for the person". ("Let there be tickling at work," Talouselämä, 2.12.2003)

At the end of the 1990s and the beginning of the 2000s, several societal reforms were launched in Finland to respond to challenges related to the aging population (Ilmarinen, 2006). Along with these reforms, age management received attention in the Talouselämä magazine; most of the organization-level articles related to age management were published between the years 2002 and 2008. After 2009, when Finland and other developed countries were influenced by the great recession (Suni and Vihriälä, 2016), interest in the organization-level focus on aging issues seems to have diminished. Inside the organization-level discourse, there was a dissonance regarding the need for age management practices and policies. On the one hand, few articles stressed the importance of organizational actively responding to the challenges related to the aging workforce. For example, one article focused on an IT company where prolonging the careers of older employees and individualized late career planning were seen to benefit younger employees as the tacit knowledge was passed from generation to generation:

Now CGI has had over one hundred discussions and made career plans for its employees aged $60+$. It is not mandatory to make a plan. If an employee does not think it is relevant, the discussion can be postponed by one year. It is also possible to change the plan. ("Over one hundred career plans for people over 60", Talouselämä, 2.5.2015)

On the other hand, some articles downplayed the importance of age management practices at the organizational level. For instance, one article titled "Discrimination or observation" discussed age management sarcastically by contesting the need for it:

The more you think about it, the more foolish the idea of age management seems. Should we really treat people of different ages differently? Probably only a few want to be considered as a representative of their own age group, similar to those who were born in the same year. In the contemporary world, age is not a symbol of either your physical or mental abilities or competencies. Perhaps the sincere goal of age management is to improve people's well-being at work and to make the descent to retirement less steep. And that's fine. (Talouselämä, 5.10.2007)

The above quotation also illustrates how aging was mainly presented as an individualoriented process in the articles that criticized the need for age management practices and policies in organizations. Interestingly, this viewpoint contradicts the prevalent social-level discourses, which consider aging employees predominantly as a homogenous group of chronologically similarly aged individuals.

\section{Discussion}


Media outlets, such as Talouselämä magazine, can be seen to promulgate prevailing norms and values related to aging in work life, as well as in society in general (Rozanova, 2010). This study examined how aging in the work-life context has been discussed at societal, organizational and individual levels, and in particular, what kind of role organizations and management was given in these discussions. The results demonstrate that the number of articles on aging in the work-life context increased slightly over the years, especially after the economic recession. However, it seems that the viewpoints on the aging topic have not broadened over the years. A deterministic and problematized perspective dominated the articles during the period under analysis.

The majority of the articles analyzed here dealt with aging as a society-level phenomenon. In the society-level discourses, aging was presented as an inevitable fact that will have considerable consequences on dependency ratios and pension systems at the national level. The dominance of society-level discourses could be the result of the actions at societal and political levels and the current social and healthcare reform that have largely dominated the current public discussion in Finland. For example, in the late 1990s to the early 2000s, the major reforms at the societal level were launched in Finland to prolong careers and anticipate changes related to the aging society (Ilmarinen, 2006). But, the prevalence of the discourses at the societal level could also relate to the economic situation in Finland during the recession. It can be expected that the societal-level issues related to aging will most likely influence the discourse in business life.

According to the articles, aging was mainly seen as a threat or a burden, and opportunities related to the aging population received less attention. Due to the aging population, the number of older consumers will increase, which will open up new business opportunities for companies (Chand and Tung, 2014). However, in the articles analyzed here, the potential business opportunities resulting from the aging population were only discussed in some consumer-centered articles.

At the individual level, aging was approached in narrow terms and mainly from a healthrelated perspective. Some articles responded to concerns related to aging, for instance, memory loss problems. Few articles focused on the active role of aging citizens. Critical analysis of the phenomenon of aging was rare, which increases the risk that aging individuals have been stereotyped into a single format and contrasted against other age groups. This can cause unnecessary confrontations (Thomas et al., 2014). Gender differences and other dimensions of diversity, which have been highlighted in the current research literature on aging (Thomas et al., 2014), were largely missing in the analyzed business articles.

When it comes to the organizational-level discussion of aging, those articles concerned about how organizations can respond to the challenges related to the aging workforce were mainly published before the recession. Although age management and age-sensitive HRM policies have received more attention in management studies in recent years (Aaltio et al., 2014), these issues did not receive much attention in the articles during the recession. Interestingly, the organizational-level discourse seemed to struggle with whether individualized management practices are needed for aging employees or not. Those articles, which acknowledged the need for age management or age-aware management can be categorized as instrumental (CSR)-HRM (Voegtlin et al., 2106) without much attention to the CSR aspects. In these articles, the need to retain aging employees was closely related to business imperatives. The other stream of organization-level articles had a pessimistic or even 
cynical tone. For example, the need for age management practices was questioned. It can be argued based on the results that the role of organizations as a responsible agency or active operator in terms of managing the challenges related to aging was largely missing.

Although the aging population is now challenging many facets at the societal, organizational and individual levels, these different levels were rarely combined and discussed in the articles. Aging was mainly linked to issues outside organizational boundaries, such as pension-related issues, changing labor markets, new business opportunities and the consumption patterns of older citizens. Whereas aging issues inside organizational boundaries, such as management practices and policies related to aging employees, were largely missing. It seems that the recent recession in Finland has influenced to some extent how aging in the work-life context has been discussed in the articles analyzed here and has given a specific tone to aging issues. The financial crisis can also explain the ambivalence found about the need for age management practices at the organizational level. In terms of the CSR-HRM perspective, specific signs for organizations willing to cater to the diverse needs of older employees were not found (see e.g. Wisse et al., 2018).

\section{Conclusions}

In conclusion, all three levels (individual, organizational and societal) were visible in the articles, but society-level discourses dominated. At the societal-level, the aging population was mainly seen as a problem, a threat or at least a challenge, which could have a negative impact, for example, on labor markets, the pension system, healthcare and the economy in general. Most of the articles were concerned about issues related to aging that take place outside organizations, such as changes in retirement legislation, the labor market and consumer behaviors. Less attention was given to the consequences of the aging workforce inside organizational boundaries, such as management practices. The passive bystander role of organizations in terms of managing the challenges related to the aging workforce was evident in the articles. Interestingly, some of the discourses seemed to contradict each other. For example, while the society-level discourses presented aging individuals mainly as a homogenous group, the individual-level discourse placed great emphasis on the active role of individuals to manage their own aging process. Based on the results, it can be concluded that internal and external organizational contexts can either promote or inhibit age management or age-aware management practices in organizations and be sensitive to other diversities as well. The current discourses on aging in the work-life context have room to be broadened in different directions. For example, the links between aging and social sustainability and CSR are likely to come up in the future, as the number of aging employees is growing rapidly.

In addition, when we juxtapose the dominance of society-level discourses with the literature on aging and ageism, our findings show the gap between organization-relevant aging research and the media. The potential and opportunities of the aging workforce could also be raised and the positive aspects of aging workforce deserve to be highlighted in the media along with the challenges and threats. Business magazines could take a more active role in promoting the information exchange between researchers and practitioners. Finally, aging research could promote media level publishing and applications of knowledge.

\section{Practical implications}


This study provides certain practical implications. The aim of this paper was to describe and analyze how aging has been manifested in a (leading) Finnish business magazine. The way aging was discussed and presented in the media is likely to influence organizational thinking patterns, decision-making processes and practices. Therefore, decision-makers, such as HR professionals and managers, in organizations should recognize the rather narrow and deterministic way of discussing the issues surrounding aging in contemporary work life. By broadening this perspective and how the aging phenomenon is seen, new management practices and possible business opportunities could emerge for organizations. The trend toward longer working lives is not likely to fade away (Lain and Loretto, 2016, p. 647). Therefore, there is a need to promote a longer work life within organizational practices and policies. Broadly speaking, organizations need to promote tolerance and equity in their age management practices (Aaltio et al., 2014). As a result, there is plenty of room for innovative age management practices and policies to respond to the future workforce challenges caused by the changing demographics. This age management or "age-aware" approach to HRM can be seen as a sustainable approach to HRM practices closely related to organizational CSR practices (Ehnert and Harry, 2012). Therefore, HRM could adopt a more influential role in promoting the social and political responsibilities of organizations to satisfy their stakeholders (including employees, families and communities as a whole).

\section{Limitations and suggestions for future research}

Several limitations of this study should be pointed out. First, the articles were only sourced from the online archive of the magazine using selected keywords. Although several search rounds were used, it is possible that a few relevant articles are still missing from the data. In addition, the focus was on textual data; therefore, future studies could investigate visual data related to aging in the media. Second, articles were only sought in the magazine Talouselämä, which provides news and articles mainly from Finnish work life. To gain a broader and even more international perspective on aging, other data sources should be used. Third, the foothold of social media is growing all the time (Whelan et al., 2013). Therefore, future studies could investigate what kinds of discourses on aging in the work-life context are prevalent in social media and whether these discourses differ compared to newspapers and magazines, for example. Furthermore, future studies could examine journalists to acquire information about what kinds of issues influence and guide their way of writing articles about aging in work life. Finally, although this study focused on aging, the aging population is commonly compared to younger age groups. Therefore, a broader focus, covering different age groups, would provide a deeper understanding of how age-related issues are discussed and presented in the media. Furthermore, the boundaries between work life and private life are becoming more blurred, because more and more older employees, for example, consider continuing working after retirement (Tenhunen, 2017). Therefore, the links between work life and other domains should be analyzed in more detail in the future.

\section{References}

Aaltio, I., Mills, A. and Helms Mills, J. (2016), "Disruptive demographics: ageing, socioeconomic change, challenges and potentialities", International Journal of Work Innovation, Vol. 1, No. 4, pp. 323-329. 
Aaltio, I., Salminen, H.M. and Koponen, S. (2014), "Ageing employees and human resource management - evidence of gender-sensitivity?”, Equality, Diversity and Inclusion: An International Journal, Vol. 33 No. 2, pp. 160-176.

Alvesson, M. \& Kärreman, D. (2000) Taking the Linguistic Turn in Organizational Research : Challenges, Responses, Consequences. The Journal of Applied Behavioral Science, Volume: 36 issue: 2, pp. 136-158.

Antoniou, A.-S., Burke, R.J., and Cooper, C.L. (2016), The Aging Workforce Handbook: Individual, Organizational and Societal Challenges, Emerald Group, Location.

Beard, J.R., Biggs, S., Bloom, D.E., Fired, L.P., Hogan, P., Kalache, A. and Oshansky, S.J. (Eds) (2012), Global Population Ageing: Peril or Promises?, Economic Forum, Geneva, available

at: http://www3.weforum.org/docs/WEF_GAC_GlobalPopulationAgeing_Report 2012.pdf (accessed 31 January 2017).

Brough, P., Johnson, G., Drummond, S. and Timms, C. (2011), "Comparisons of cognitive ability and job attitudes of older and younger workers", Equality Diversity and Inclusion: An International Journal, Vol. 30 No. 2, pp. 105-126.

Buyens, D., Van Dijk, H., Dewilde, T. and De Vos, A. (2009), "The aging workforce: perceptions of career ending", Journal of Managerial Psychology, Vol. 24 No. 2, pp. $102-117$.

Calasanti, T.M. and Slevin, K.F. (2006), "Introduction: age matters", in Calasanti, T.M. and Slevin, K.F. (Eds), Age Matters: Realigning Feminist Thinking, Routledge, New York, pp. 1-17.

Carone, G., Eckefeldt, P., Giamboni, L., Laine, V. \& Pamies Sumner, S. (2016) "Pension reforms in the EU since the early 2000's: Achivements and challenges ahead. Discussion Paper 042, available at: https:/ec.europa.eu/info/publications/economyfinance/pension-reforms-eu-early-2000s-achievements-and-challenges-ahead en (accessed 5 May 2018)

Cattell, R.B. (1943), “The measurement of adult intelligence”, Psychological Bulletin, Vol. 40 No. 3, pp. 153-193.

Cattell, R.B. (1987), Intelligence: Its Structure, Growth, and Action, North-Holland, Amsterdam.

Chand, M. and Tung, R.L. (2014), “The aging of the world's population and its effects on global business", The Academy of Management Perspectives, Vol. 28 No. 4, pp. 409429.

Coughlin, J.F. (2010, April 14), "Blended futures of aging \& business innovation", EzineArticles, available at: http://ezinearticles.com/?Blended-Futures-of-Aging-andBusiness-Innovation\&id=4113183 (accessed 30 October 2012).

Ehnert, I. and Harry, W. (2012), "Recent developments and future prospects on sustainable human resource management", Management Revue, Vol. 23 No. 3, pp. 221-238.

Erikson, P. and Kovalainen, A. (2014), Qualitative Methods in Business Research, 2nd ed., Sage, London.

Fineman, S. (2014), “Age matters”, Organization Studies, Vol. 35 No. 11, pp. 1719-1723.

Foster, L. and Walker, A. (2013), "Gender and active ageing in Europe", European Journal of Aging, Vol. 10 No. 1, pp. 3-10. 
Gee, E.M. and Gutman, G.M. (2000), The Overselling of Population Aging: Apocalyptic Demography, Intergenerational Challenge, and Social Policy, Oxford University Press, New York.

Gioia, D.A., Corley, K.G. and Hamilton, A.L. (2012), "Seeking qualitative rigor in inductive research: notes on the Gioia methodology", Organisational Research Methods, Vol. 16 No. 1, pp. 15-31.

Hardy, C. (2004), "Scaling up and bearing down in discourse analysis: questions regarding textual agencies and their context", Organization, Vol. 11 No. 3, pp. 415-425.

Hedge, J.W., Borman, W.C. and Lammlein, S.E. (2006), The Aging Workforce: Realities, Myths, and Implications for Organizations, American Psychological Association, Washington, DC.

Henkens, K., Remery, C. and Chippers, J. (2008), "Shortage in aging labour market: an analysis of employers' behavior", The International Journal of Human Resource Management, Vol. 19 No. 7, pp. 1314-1329.

Hertel, G., Van der Heijden, B.I.J.M., De Lange, A.H. and Deller, J. (2013), "Facilitating age diversity in organizations - part I: challenging popular misbeliefs", Journal of Managerial Psychology, Vol. 28 No. 7/8, pp. 729-740.

Ilmarinen, J. (2001), “Aging workers", Occupational and Environmental Medicine, Vol. 58 No. 8, pp. 546-552.

Ilmarinen, J. (2006), Towards a Longer Worklife! Ageing and the Quality of Worklife in the European Union, Finnish Institute of Occupational Health and Ministry of Social Affairs, Helsinki, p. 467.

Kanfer, R. and Ackerman, P.L. (2004), “Aging, adult development, and work motivation", Academy of Management Review, Vol. 29 No. 3, pp. 440-458.

Lain, D. and Loretto, W. (2016), "Managing employees beyond age 65: from the margins to the mainstream?", Employee Relations, Vol. 38 No. 5, pp. 646-664.

Laliberte Rudman, D. (2015), "Embodying positive aging and neoliberal rationality: talking about the aging body within narratives of retirement", Journal of Aging Studies, Vol. 34, pp. 10-20.

Laliberte Rudman, D. and Molke, D. (2009), "Forever productive: the discursive shaping of later life workers in contemporary Canadian newspapers", Work, Vol. 32, pp. 377-389.

Leung, A.S.M. (2000), "Gender differences in Guanxi-behaviours: an examination of PRC state-owned enterprises", International Review of Women and Leadership, Vol. 6 No. 10, pp. $48-59$.

Mahon, J.F. and Millar-Schijf, C.C.J.M. (2014), "ManAGEment: the challenges of global age diversity for corporations and governments", Journal of Organizational Change Management, Vol. 27 No. 4, pp. 553-568.

Palloni, A. and McEniry, M. (2007), "Aging and health status of elderly in Latin America and the Caribbean: preliminary findings", Journal of Cross-Cultural Gerontology, Vol. 22 No. 3, pp. 263-285.

Parry, E. and Tyson, S. (2009), "Organizational reactions to UK age discrimination legislation", Employee Relations, Vol. 31 No. 5, pp. 471-488.

Pfeffer, J. (2010), "Building sustainable organizations: the human factor", Academy of Management Perspective, Vol. 2, pp. 34-45. 
Phillips, N. and Hardy, C. (2002), Understanding Discourse Analysis: Investigating Processes of Social Construction, Sage, Thousand Oaks.

Rozanova, J. (2010), "Discourse of successful aging in The Globe and Mail: insights from critical gerontology”, Journal of Aging Studies, Vol. 24, pp. 213-222.

Sonnet, A., Olsen, H. and Manfredi, T. (2014), "Towards more inclusive ageing and employment policies: the lessons from France, The Netherlands, Norway and Switzerland", De Economist, Vol. 162, pp. 315-339.

Statistics Finland (2015), "Population projection. Appendix table 1. Population by age 19002060 (years 2020 to 2060: projection)", Statistics Finland, Helsinki, available at: http://www.stat.fi/til/vaenn/2015/vaenn_2015 2015-10-30 tau 001 en.html (accessed 30 September 2017).

Sterns, H.L. and Miklos, S.M. (1995), "The aging employee in a changing environment: organizational and individual issues", Journal of Vocational Behavior, Vol. 47 No. 3, pp. $248-268$.

Strandberg, C. (2009), The Role of Human Resource Management in Corporate Social Responsibility Issue Brief and Roadmap, Strandberg Consulting, Burnaby.

Suni, P. and Vihriälä, V. (2016). "Finland and Its Northern Peers in the Great Recession".

ETLA Reports No 49, available at: http://pub.etla.fi/ETLA-Raportit-Reports-49.pdf (accessed 16 May 2018).

Talouselämä (Economic Life), 2.12.2003; 29.3.2007; 5.10.2007; 3.12.2008; 27.5.2009; 25.11.2010; 19.1.2011; 6.5.2011;3.6.2011;30.8.2012; 2.5.2015; 27.12.2016

Tenhunen, S. (2017), "Eläkeikä nousee mutta joustot säilyvät. Kyselytutkimus vuoden 2017 eläkeuudistuksesta ja työssäjatkamisaikeista" [Retirement age will rise but flexibility will remain. Survey regarding year 2017 pension reform and intentions to continue working] Eläketurvakeskuksen tutkimuksia 05/2017, available at: http://www.etk.fi/wpcontent/uploads/elakeika-nousee-mutta-joustot-sailyvat-1.pdf (accessed 4 May 2018).

Thomas, R., Hardy, C., Cutcher, L. and Ainsworth, S. (2014). "What's age got to do with it? On the critical analysis of age and organizations", Organization Studies, Vol. 35 No. 11, pp. 1569-1584.

Voegtlin, C., and Greenwood, M. (2016), "Corporate social responsibility and human resource management: a systematic review and conceptual analysis", Human Resource Management Review, Vol. 26 No. 3, pp. 181-197.

Vaara, E. \& Tienari, J. (2002), Justification, legitimation and naturalization of mergers and acquisitions: A critical discourse analysis of media texts. Organization, 9(2), pp. 275303.

Walker, A. (2005), "The emergence of age management in Europe", International Journal of Organisational Behaviour, Vol. 10 No. 1, pp. 685-697.

Wang, Q. and Aaltio, I. (2017), "Social entrepreneurship - discourses and contributions: a literature analysis", Electronic Journal of Business and Ethics and Organization Studies, Vol. 22 No. 2, pp. 14-23.

Whelan, G., Moon, J. and Grant, B. (2013), "Corporations and citizenship arenas in the age of social media”, Journal of Business Ethics, Vol. 118 No. 4, pp. 777-790. 
Wisse, B., van Eijbergen, R., Rietzschel, E.F. and Scheibe, S. (2018), "Catering to the needs of an aging workforce: the role of employee age in the relationship between corporate social responsibility and employee satisfaction", Journal of Business Ethics, available at: https://doi.org/10.1007/s10551-015-2983-8 (accessed 30 April 2018). 
Table I. Themes

\begin{tabular}{llc}
\hline Themes & $\begin{array}{c}\text { The number of } \\
\text { articles }\end{array}$ \\
\hline 1 Aging and its influences on society & 17 \\
2 & Aging as a business opportunity & 15 \\
3 & Consequences of aging on work life & 7 \\
4 & Consequences of aging on individuals & 11 \\
5 & Pension-related issues & 9 \\
6 & Society-level policies needed to respond to the aging population & 6 \\
7 & Organization-level age management practices and policies & 16 \\
\hline
\end{tabular}




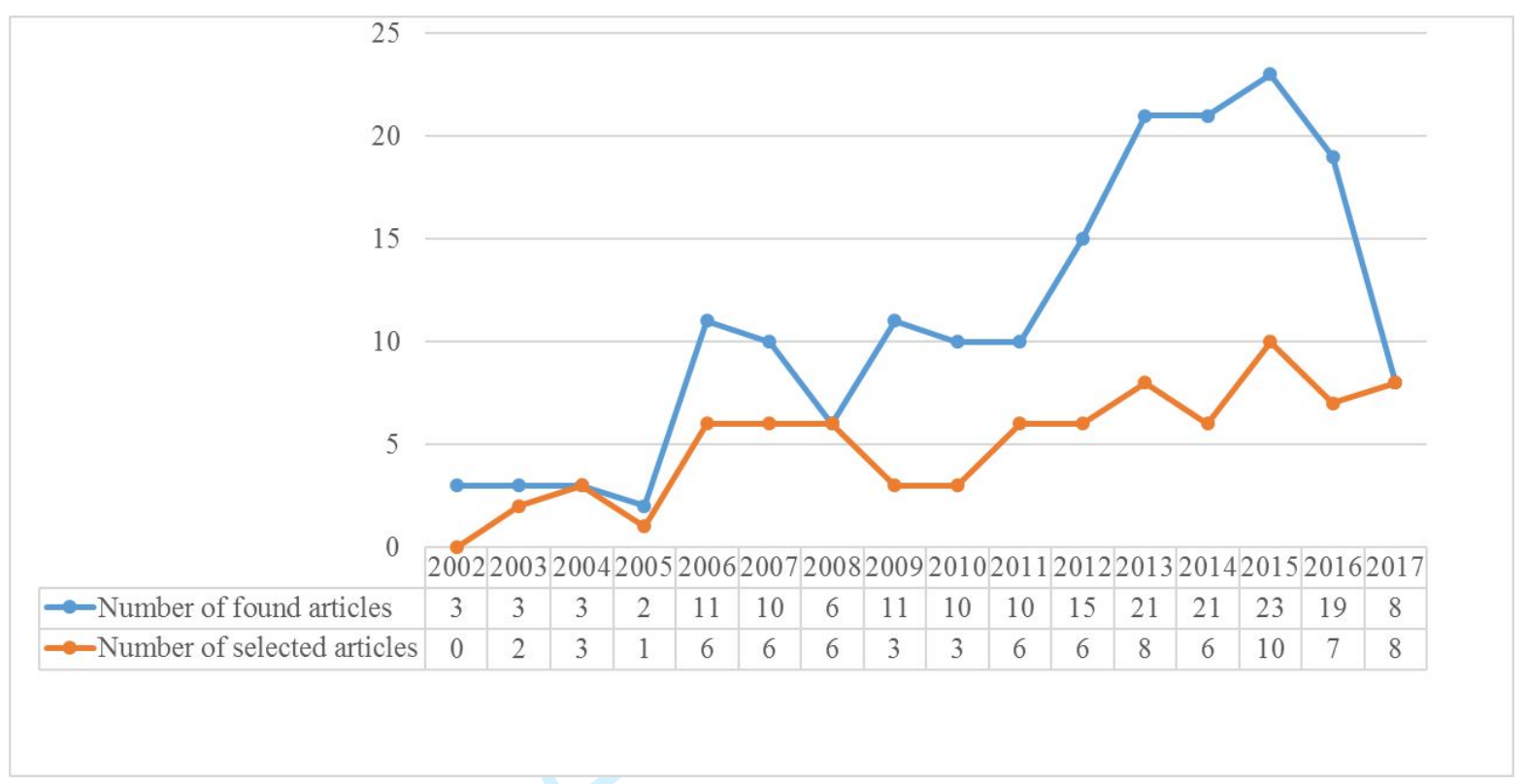

Figure I. Distribution of the articles in Talouselämä magazine during the years 2002-2017 